\title{
Records of different habitats used by the Colo-Colo (Leopardus colocola colocola) Molina 1782, in Central Chile
}

\section{Registros de diferentes hábitats usados por el Colo-Colo (Leopardus colocola colocola) Molina 1782, en la zona central de Chile}

\section{Carlos Castro-Pastene ${ }^{1, *}$, Cristian González², Héctor Carrasco² \& Mauricio Soto-Gamboa ${ }^{3}$}

${ }_{1}^{1}$ Programa de Magíster en Ecología Aplicada, Instituto de Ciencias Ambientales y Evolutivas, Facultad de Ciencias, Universidad Austral de Chile, Valdivia, Chile. 2DASP, Región del Maule, CONAF, Chile.

${ }^{3}$ Instituto de Ciencias Ambientales y Evolutivas, Facultad de Ciencias, Universidad Austral de Chile, Valdivia, Chile.

*E-mail: ccastropastene@gmail.com

\begin{abstract}
The Colo-Colo (Leopardus colocola) has a wide geographical distribution in South America. We document different types of habitats like forestal plantations, vineyard, hydrophilic, and deciduous forest, coastal desert, and Andean Steppe that it uses in Central Chile through trail cameras and direct observations. In this study, this cat was registered both in natural and heavily modified environments. More information is needed to understand if this felid's records in intervened areas are mostly associated with movements between patches of native vegetation or regular use.
\end{abstract}

Palabras clave: carnívoro, esclerófilo, pequeño felino, punto caliente, selección de hábitat.

RESUMEN

El gato Colo-Colo (Leopardus colocola) tiene una amplia distribución en Sudamérica. A través de cámaras trampas y observaciones directas, documentamos diferentes hábitats como plantaciones forestales, viñas, bosque hidrófilo y caducifolio, desierto costero y Estepa Andina que utiliza en Chile Central. En este estudio, este felino fue registrado en ambientes naturales y altamente intervenidos. Se necesita más información para entender si los registros de este felino en áreas intervenidas están asociados a movimientos entre parches de vegetación nativa o a un uso regular.

Keywords: carnivore, habitat selection, hotspot, sclerophyllous, small cat.

The Colo-Colo (Leopardus colocola) or Pampas cat is one of the least known of the South American wild cat species, in spite of its wide geographical distribution in South America, ranging from Ecuador to the Argentinean Patagonia and from east to west from Brazil to Chile (Nowell \& Jackson 1996). The most recent taxonomic review by the Cat Specialist group (Kitchener et al. 2017) establishes seven subspecies with a great genetic difference. Recently, Nascimento et al. (2020), has made a new taxonomic proposal for the species but have not been assessed or approved by the IUCN Cat Specialist Group.

The subspecies have a great genetic difference, which although it is not enough to declare them full species, these must be considered as distinct administrative units (Johnson et al. 2006; Cossios et al. 2009). These subspecies are L. c. garleppi Matschie, 1912, that is present in Ecuador, Peru and Bolivia (Cossios et al. 2009; Kitchener et al. 2017; Santos et al. 2018) although some authors postulate based 
on personal observations that this feline would also be found in Colombia (Alberico et al. 2000). This subspecies inhabits the altiplano (Garcia-Perea, 2002; Cossios et al. 2009; Villalba et al. 2012; Huaranca et al. 2019) in coastal mangroves (García-Olaechea et al. 2013; García-Olaechea \& Hurtado 2017) mainly on the east side of the Peruvian Andes (Kitchener et al. 2017). L. c. budini Pocock, 1941, inhabiting the northwest side of the Argentine Andes (García-Perea 1994). L. c. braccatus Cope, 1889 in Bolivia, Paraguay and central Brazil inhabiting swampy areas, cattle grazing areas, wet and dry tropical forests, grasslands, scrubland, savanna, desert (Silveira 1995; Nascimento et al. 2016). L. c. munoai Ximénez, 1961 in southern Brazil, Uruguay and northwestern Argentina (Garcia-Perea 2002; Kitchener et al. 2017; Santos et al. 2018) L. c. pajeros Desmarest, 1816 all over theArgentinean pampas (Garcia-Perea 1994; Kitchener et al. 2017) L. c. wolffshoni Garcia-Perea, 1994 in the Chilean altiplano (Napolitano et al. 2008; Cossios et al. 2009; Santos et al. 2018) and L. c. colocola in the central Chile (Cossios et al. 2009; Kitchener et al. 2017; Santos et al. 2018). L. c. colocola is one of the least known of the subspecies, as the used habitats, are not properly described, and most of the natural history remains undescribed (time of activity, densities, factors driving the population trends, etc). The central zone of Chile it is one of the 34 biodiversity hotspots worldwide (Myers et al. 2000) and this habitat (where this subspecies lives) has been heavily intervened (Echeverria et al. 2006). For this reason, in this note we report the records we have obtained of Colo-Colo cats from the central zone of Chile.

Here we present records that corresponding to images from camera traps placed in and around two protected areas: the Radal Siete Tazas National Park (RSTNP) and Altos de Lircay National Reserve (ALNR). The camera traps were installed at the bottom of streams, humid areas and with the presence of rhizomes in the RSTNP because the objective of the study was the wild boar. The camaras traps were installed from march to November of 2013 and for these stations olfactory attractor for wild boar was used. The camera traps in ALNR were installed in wildlife crossing. The camera traps were installed in August 2018 and are still active today. Lynx urine is used as bait for these stations

In addition, two direct observations are added, one from the Libertador Bernardo O'Higgins Region and the other in the Atacama Region. The field markings that allowed us to attribute these records to Leopardus colocola were the rings on their legs.

The Pampas cat was registered in six different environments, two of those strongly altered by human activities (vineyard and plantation forestry). The Colo-Colo was also captured in three environments dominated by native vegetation. The last record was in the intertidal area of a coastal desert (Fig. 1).

The records of Pampas cat from Chile's central region are scarce and scientific reports about their ecology nonexistent. Thus, our records (Fig. 2) contribute to the knowledge of the natural history of this felid. At the beginning of the $20^{\text {th }}$ century, Wolffsohn (1907) described this feline as abundant in Central Chile (Based on observations without following any methodology), specifically in Valparaíso, Santiago, and Quillota. Therefore, we infer that the human demographic expansion (Based on the growth of cities in the central area of the country and because in some there are no longer natural areas) has strongly affected the populations of this subspecies. One of the main causes of death in all the subspecies of the Pampas cat is run over by cars (Chebez et al. 2008; Fandinho et al. 2014; Nascimento et al. 2016). We argue this may be the case also for Central Chile. Because anthropogenic mortality is one of the most important threats to felids worldwide (Loveridge et al. 2010), it is necessary to assess how human activity affects the populations of this small cat.

TABLE 1. Description of habitat type, record source, location and geographical coordinates of each observation. / Descripción de los tipos de hábitats, tipos de registros, localidad y coordenadas geográfica de cada observación.

\begin{tabular}{lccc}
\hline Habitat & Record & Location & UTM \\
\hline Coastal desert & Pers. Obs. M.O. & Punta de Choros & $259007.00 / 6766162.00$ \\
Hydrophilic Forest & trail-camera & RSTNP & $320505.14 / 6073426.62$ \\
Deciduous Forest & trail-camera & ALNR & $328119.37 / 6059377.58$ \\
Maule High Andean Steppe & trail-camera & ALNR & $318656.99 / 6060611.25$ \\
Vineyard & Pers. Obs. & Peumo & $292410.86 / 6264539.60$ \\
Plantation forestry & trail-camera & RSTNP & $323263.70 / 6087271.08$ \\
\hline
\end{tabular}




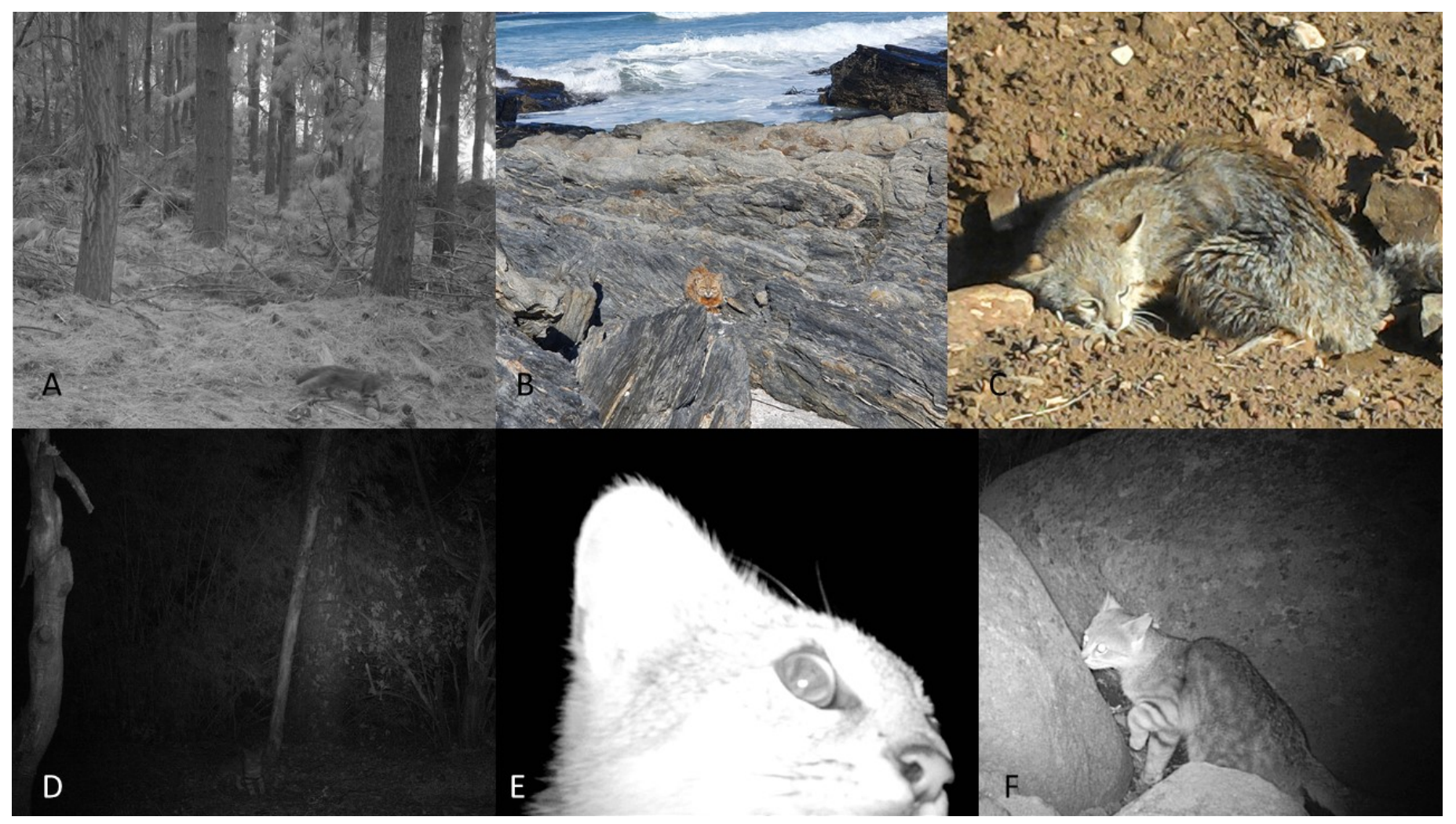

Figure 1. Photographic records of Colo-Colo in figure A) a forest plantation near RSTNP. B) the intertidal at the coastal desert, Atacama region. C) a vineyard in the O'Higgins region. D) at RSTNP in a hydrophilic forest environment. E) at ALNR in a deciduous forest. F) at ALNR in the high Andean steppe of Maule. / Registros fotográficos del gato Colo-Colo en figura A) plantación forestal cerca de PNRST. B) el intermareal del desierto costero de la Región de Atacama. C) una viña en la Región de O'Higgins. D) PNRST en bosque hidrófilo. E) RNAL en bosque caducifolio. F) RNAL en estepa andina del Maule.

The distribution of L. C. colocola subspecies has historically been described from Coquimbo to Concepción (Iriarte 2008; Muñoz-Pedreros \& Yañez 2009; Iriarte \& Jaksic 2017). However, new records have reported the colocolo cat placed as far as the Atacama Desert in Llanos del Challe National Park (Espinoza et al. 2014). In addition to our record we propose a new distribution of the subspecies that would go from Llanos del Challe National Park to Concepción. Although there are records in the Antofagasta Region of Leopardus colocola that have been attributed to L. c. colocola; (Rau et al. 2015), we postulate that they would not correspond to this subspecies, but rather to L. C. wolffshoni due to the proximity they would have with this population. Records in desert areas reported by Espinoza et al. (2014), in addition to the ones we report here, shows the great capacity of this species to adapt to different environments.

In fragmented landscapes, some native species may move through the matrix surrounding remnants of core habitat areas (Lindenmayer et al. 1999). However, wildlife use of modified lands may depend on the landscape configuration of these areas and the size of the remaining patches of natural habitat (Aberg et al. 1995; Dunn 2000). For example, the güiña (Leopardus guigna) is a small feline strictly associated with native forest habitats (Acosta-Jamett \& Simonetti 2004) that in altered habitats can use farmlands to move between forest patches (Galvez et al. 2017). In order to learn more about the ecology of this species and its conservation status. It would be important to understand whether the records we obtained of pampas cats in habitats, such as vineyards and forest plantations, are associated with regular use. That are temporarily alternative habitats but of lower quality or simply corresponds to quick movements between patches of natural habitats.

It should be noted that we registered this small feline for the first time in a forest plantation. Our records agree with those of Nanni et al. (2020), who documented the pampas cat in natural and intervened environments. To understand the use of habitat and ecology of this feline it is necessary to carry out more research to understand the adaptability of this feline to new environments. Whether natural or anthropic, like 
Garcia et al. (2020), We registered pampas cat in vineyards. Although the Colo-Colo cat can inhabit monocultures, it seems to be much less abundant than in other types of open environments because they are less structurally diverse, which would provide less shelter and prey (Nanni et al. 2020). Although there is an information gap on how the change in land use would affect this carnivore, this could likely lead to this species to local extinctions such as in central Argentina
(Pereira et al. 2002). Like most carnivores, this small feline has high household range requirements (Telleache 2015; Ojeda 2019). Probably state-protected wilderness areas are not large enough (each on their own) to support a population of this small wild cats, so private areas are critical to their conservation so vineyards and forest plantations can serve as corridors.

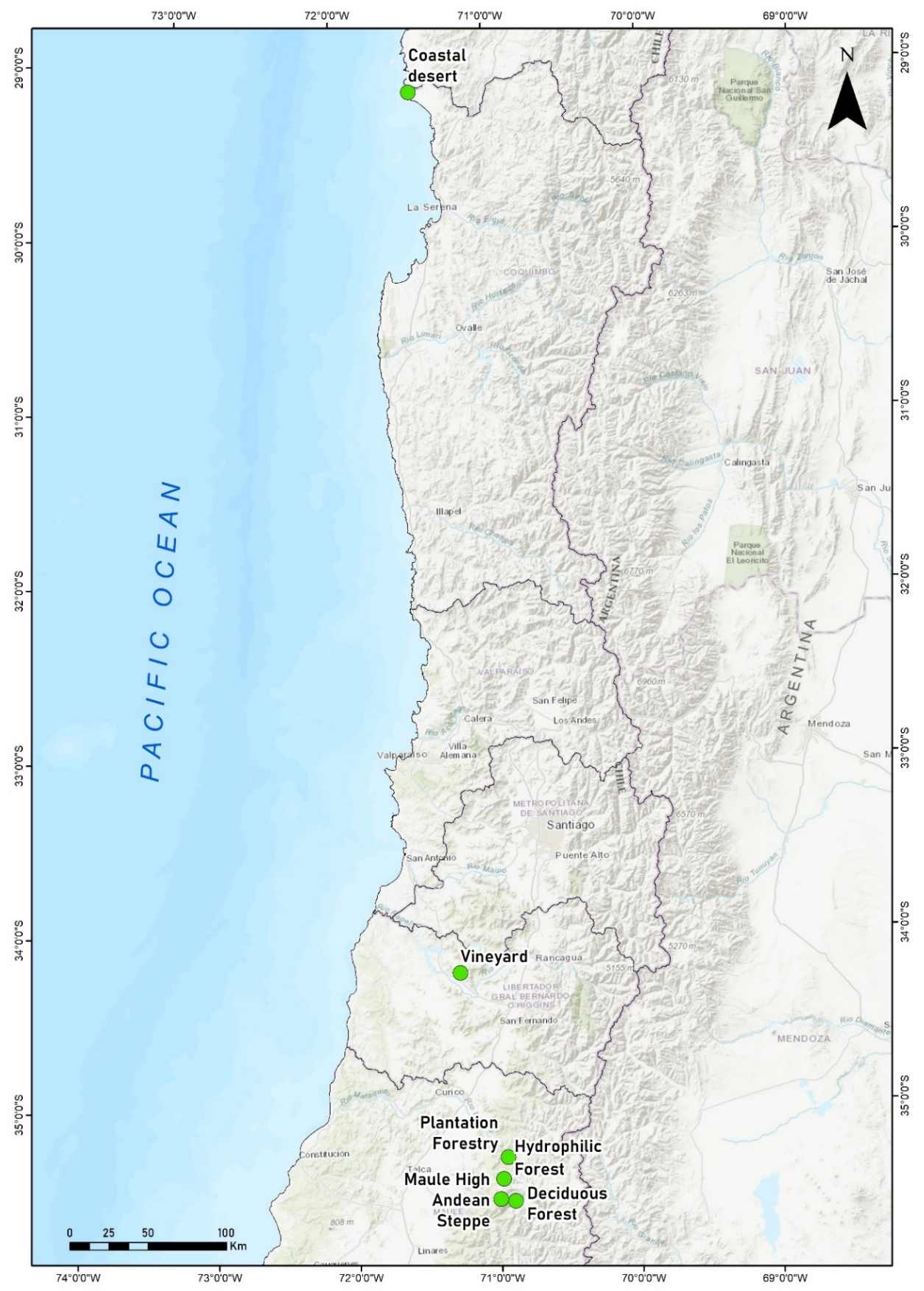

Figure 2. Records of Leopardus colocola of this study. / Registros de Leopardus colocola de este estudio. 
Although there are no studies on the use of habitats or population dynamics in Gato Colo-Colo that allow us to know the current state in the central zone of Chile, it seems that anthropic activities such as changes in land use, fires, and run overs are the main ones. Due to the decline of this species. It is critically necessary to ensure its conservation to carry out habitat use studies in the central zone of Chile.

\section{ACKNOWLEDGMENTS}

To Mario Opazo for his photographs at Punta de Choros and Conaf for the support. To Jacqueline Pastene for her efforts to record Pampas cats in vineyard areas, Natalia Valenzuela for her great help with the maps in several projects, Alexis Villa and Oscar Skewes for their help; and finally, to CONAF for financing the project "Jabalí en Radal Siete Tazas".

\section{REFERENCES}

Aberg, J., Jansson, G., Swenson, J.E., Angelstam, P. 1995. The effect of matrix on the occurrence of hazel grouse (Bonasa bonasia) in isolated habitat fragments. Oecologia 103(3): 265-269.

Acosta-Jamett, G., Simonetti, J. 2004. Habitat use by Oncifelis guigna and Pseudalopex culpaeus in a fragmented forest landscape in central Chile. Biodiversity and Conservation 13(6): 1135-1151.

Alberico, M., Cadena, A., Hernández-Camacho, J., Muñoz-Saba, Y. 2000. Mamíferos (Synapsida: Theria) de Colombia. Biota Colombiana 1(1): 43-75.

Chebez, J.C., Nigro, N., Solís, G.A., Strumia, A.T. 2008. Confirmación de la presencia del gato del pantanal Lynchailurus braccatus (Cope, 1889) en la Argentina. Notas Faunísticas 19(2): 1-11.

Cossíos, D., Lucherini, M., Ruiz-García, M., Angers, B. 2009. Influence of ancient glacial periods on the Andean fauna: The case of the pampas cat (Leopardus colocolo). BMC Evolutionary Biology 9: 68.

Dunn, R.R. 2000. Isolated trees as foci of diversity in active and fallow fields. Biological Conservation 95(3): 317-321.

Echeverría, C., Coomes, D., Salas, J., Rey-Benayas, J. M., Lara, A., Newton, A. 2006. Rapid deforestation and fragmentation of Chilean temperate forest. Biological Conservation 130: 481-494.

Espinosa, M., Cepeda-Mercado, A., Louit, C., Meléndez, M.; González-Maya, J.F. 2014. Pampas cat Leopardus colocolo in the atacama desert: first records from llanos de challe national park, Chile. Boletín del Museo Nacional de
Historia Natural (Chile) 63: 111-118.

Fandiño, B., Rozzatti, J.C., Del Barco, D., Civetti, R. 2014. Nuevo registro documentado del gato de pajonal (Leopardus colocolo) (Desmarest, 1816) en Santa Fé, Argentina. Biológica 17: 62-64

Galvez, N., Guillera-Arroita, G.S., John, F.A., Schuttler, E., Macdonald, D.W., Davies, Z.G. 2018. A spatially integrated framework for assessing socioecological drivers of carnivore decline. Journal of Applied Ecology 55(3): 1393-1405.

García-Olaechea, A., Chávez-Villavicencio, C., Novoa, J. 2013. Leopardus pajeros (Desmarest, 1816) (Carnivora: Felidae) in Northern Peru: First record for the department of Piura, at the Mangroves San Pedro de Vice, and geographic extention. Check List 9(6): 1596-1599.

García-Olaechea, A., Hurtado, C. 2017. Assessment of the current distribution and human perceptions of the Pampas cat Leopardus colocolo in northern Peru and southern Ecuador. Oryx 52(3): 587-590.

Garcia-Perea, R. 1994. The pampas cat group (Genus Lynchailurus Severtzov, 1858) (Carnivora: Felidae), a systematic and biogeographic review. American Museum Novitates 3096: 1-36.

García-Perea, R. 2002. Andean mountain cat, Oreailurus jacobita: Morphological description and comparison with other felines from the Altiplano. Journal of Mammalogy 83(1): 110-124.

Huaranca, J.C., Villalba, M.L., Negroes, N., Jimenez, J.E., Macdonald, D.W., Pacheco, L. 2019. Density and activity patterns of Andean cat and pampas cat (Leopardus jacobita and L. colocolo) in the Bolivian Altiplano. Wildlife Research 47(1): 68-76.

Iriarte, A. 2008. Mamíferos de Chile. Lynx Edicions. Barcelona, España. 420 pp.

Iriarte, A., Jaksic, F. 2012. Los carnívoros de Chile. Ediciones Flora \& Fauna Chile y CASEB, P. U. Católica de Chile. 260 pp.

Johnson, W.E., Eizirik, E., Pecon-Slattery, J., Murphy, W.J., Antunes, A., Teeling, E., O'Brien, S.J. 2006. The late Miocene radiation of modern Felidae: $A$ genetic assessment. Science 311(5757): 73-77.

Kitchener, A.C., Breitenmoser-Würsten, C., Eizirik, E., Gentry, A., Werdelin, L., Wilting, A., Yamaguchi, N., Abramov, A.V., Christiansen, P., Driscoll, C., Duckworth, J.W., Johnson, W., Luo, S.-J., Meijaard, E., O’Donoghue, P., Sanderson, J., Seymour, K., Bruford, M., Groves, C., Hoffmann, M., Nowell, K., Timmons, Z., Tobe, S. 2017. A revised taxonomy of the Felidae. The final report of the Cat Classification Task Force of the IUCN/SSC Cat Specialist Group. Cat News Special Issue 11. 80 pp.

Laurance, W.F. 1991. Ecological correlates of extinction 
proneness in Australian tropical rainforest mammals. Conservation Biology 5(1): 79-89.

Lindenmayer, D.B., Cunningham, R.B., Pope, M.L. 1999. A largescale "experiment" to examine the effects of landscape context and habitat fragmentation on mammals. Biology Conservation 88(3): 387-403.

Loveridge, A., Wang, S.W., Frank, L.G., Seidensticker, J. 2010. People and wild felids: conservation of cats and management of conflict. En: McDonald, D., Loveridge, A. (Eds.) Biology and conservation of wild felid: 161-196. Oxford University Press.

Muñoz-Pedreros, A., Yañez, J. 2009. Mamíferos de Chile. Segunda edición. Cea Ediciones. Valdivia, Chile. 571 pp.

Myers, N., Mittermier, R.A., Mittermier, C.G., da Fonseca, G.A.B., Kent, J. 2000. Biodiversity hotspots for conservation priorities. Nature 403: 853-858.

Napolitano, C., Bennett, M., Jhonson, W.E., O’Brien, S.J., Marquet, P.A. Barria, I., Poulin, E., Iriarte, A. 2009. Ecological and biogeographical inferences on two sympatric and enigmatic Andean cat species using genetic identification of faecal samples. Molecular Ecology 17(2): 678-690.

Nanni, A.S., Castro, L., Cuyckens, G.A.E., Barri, F.R., Giordano, A., Lucherini, M. 2020. New Pampas cat, Leopardus colocola (Molina, 1782) (Mammalia: Carnivora: Felidae), records for the Chaco ecoregion raise questions on the distribution and population status of this felid in Argentina. Checklist 16: 729-735.

Nascimento, P., Santos, P., Passamani, M. 2016. Range extension of the Pantanal cat Leopardus braccatus (Carnívora, Felidae) in a Cerrado-Caatinga-Atlantic Forest ecotone, Brazil. Mastozoología Neotropical 23(1): 171-177.

Nascimento, F.O.D., Cheng, J., Feijó, A. 2020. Taxonomic revision of the pampas cat Leopardus colocola complex (Carnivora: Felidae): an integrative approach. Zoological Journal of the Linnean Society: zlaa043. https://doi.org/10.1093/ zoolinnean/zlaa043

Nowell, K., Jackson, P. 1996. Wild Cats: Status survey and conservation action plan. International Union for Conservation of Nature and Natural Resources - IUCN. Gland Switzerland. 383 pp.

Ojeda, R. 2019. Área de acción de Leopardus colocolo Molina, 1782 "gato del pajonal", Manglares de San Pedro de Vice, Piura-Perú. Tesis. Universidad Nacional de Piura, Piura, Perú.

Pereira, J., Varela, D., Fracassi, N. 2002. Pampas cat in Argentina: is it absent from the Pampas? Cat News 36: 20-22.

Rau, J., Zuleta, C., Gantz, A., Iriarte, J.A. 2015. Nuevos registros del gato colocolo, Leopardus colocolo colocolo (Carnivora: Felidae), en el desierto de Atacama, Región de Antofagasta, Norte Grande de Chile. Gayana 79(2): 208-211.

Santos, A., Campos, T., Gomes de Oliveira, T., Silveira, L., Eizirik, E., 2018. Phylogeographic analyses of the pampas cat (Leopardus colocola; Carnivora, Felidae) reveal a complex demographic history. Genetics and Molecular Biology 41(1): 273-287.

Silveira, L. 1995. Notes on the distribution and natural history of the pampas cat, Felis colocolo, in Brazil. Mammalia 59(2): 284-288.

Tellaeche, C. 2015. Ecología y uso del espacio de dos especies de félidos, Gato Andino (Leopardus jacobita) y Gato del Pajonal (L. colocolo) en la región Altoandina, Prov. De Jujuy. Tesis de Doctorado. Universidad Nacional del Sur, Bahía Blanca, Argentina.

Villalba, M.L., Bernal, N., Nowell, K., Macdonald, D.W. 2012. Distribution of two Andean small cats (Leopardus jacobita and Leopardus colocolo) in Bolivia and the potential impacts of traditional beliefs on their conservation Endangered species research. 16: 85-94.

Wolffshon, J.A. 1908. Contribuciones a la mamalojia Chilena. Revista Chilena de Historia Natural 12(3): 165-172.

Received: 27.02.2020

Accepted: 08.03.2021 